1 A rapid pharmacogenomic assay to detect $N A T 2$ polymorphisms and guide isoniazid dosing

4 Renu Verma ${ }^{1}$, Sunita Patil ${ }^{1}$, Nan Zhang $^{2}$, Flora M.F. Moreira ${ }^{3}$, Marize T. Vitorio ${ }^{3}$, Andrea da S.

5 Santos $^{3}$, Ellen Wallace ${ }^{4}$, Devasena Gnanashanmugam ${ }^{4}$, David Persing ${ }^{4}$, Rada Savic ${ }^{2}$, Julio

6 Croda $^{5,6}$, Jason R. Andrews ${ }^{1 *}$

1. Division of Infectious Diseases and Geographic Medicine, Stanford University School of Medicine, Stanford, CA, USA

2. Department of Bioengineering and Therapeutic Sciences, University of California, San Francisco, CA, USA

3. Federal University of Grande Dourados, Dourados, Brazil

4. Cepheid Inc., Sunnyvale, California, USA

5. Postgraduate Program in Infectious and Parasitic Diseases, Federal University of Mato Grosso do Sul, Mato Grosso do Sul, Brazil

\title{
18 Correspondence*
}

19 Jason Andrews, MD

20 Division of Infectious Diseases and Geographic Medicine

21 Biomedical Innovations Building, Room 3458

22 Stanford University School of Medicine

23 Stanford, CA 94305 
medRxiv preprint doi: https://doi.org/10.1101/2021.01.17.21249995; this version posted March 4, 2021. The copyright holder for this preprint (which was not certified by peer review) is the author/funder, who has granted medRxiv a license to display the preprint in perpetuity. All rights reserved. No reuse allowed without permission.

24 Email: jandr@stanford.edu

25 Phone: +16504972679

26

27 Running title: A rapid pharmacogenomic assay for isoniazid dosing

28

29 Summary: This manuscript describes the development and validation of point-of-care multiplex

30 pharmacogenomic assay to guide personalized dosing of isoniazid for treatment or prevention of

31 tuberculosis.

32 
medRxiv preprint doi: https://doi.org/10.1101/2021.01.17.21249995; this version posted March 4, 2021. The copyright holder for this preprint (which was not certified by peer review) is the author/funder, who has granted medRxiv a license to display the preprint in perpetuity.

All rights reserved. No reuse allowed without permission.

\section{Abstract}

34 Rationale: Standardized weight-based dose of anti-tubercular drugs contributes to a substantial

35 incidence of toxicities, inadequate treatment response, and relapse, in part due to variable drug

36 levels achieved. Single nucleotide polymorphisms (SNPs) in the N-acetyltransferase-2 (NAT2)

37 gene explain the majority of interindividual pharmacokinetic variability of isoniazid (INH).

38 However, an obstacle to implementing pharmacogenomic-guided dosing is the lack of a point-of-

39 care assay.

40 Objectives: To develop and test a NAT2 classification algorithm, validate its performance in

41 predicting isoniazid clearance, and develop a prototype pharmacogenomic assay.

42 Methods: We trained random forest models to predict $N A T 2$ acetylation genotype from

43 unphased SNP data using a global collection of 8,561 phased genomes. We enrolled 48

44 pulmonary TB patients, performed sparse pharmacokinetic sampling, and tested the acetylator

45 prediction algorithm accuracy against estimated INH clearance. We then developed a cartridge-

46 based multiplex qPCR assay on the GeneXpert platform and assessed its analytical sensitivity on

47 whole blood samples from healthy individuals.

48 Measurements and Main Results: With a 5-SNP model trained on two-thirds of the data

$49(\mathrm{n}=5,738)$, out-of-sample acetylation genotype prediction accuracy on the remaining third

$50(n=2,823)$ was $100 \%$. Among the 48 TB patients, predicted acetylator types were: $27(56.2 \%)$

51 slow, $16(33.3 \%)$ intermediate and 5 (10.4\%) rapid. INH clearance rates were lowest in predicted

52 slow acetylators (median 19.3 L/hr), moderate in intermediate acetylators (median $41.0 \mathrm{~L} / \mathrm{hr}$ ) and

53 highest in fast acetylators (median $46.7 \mathrm{~L} / \mathrm{hr}$ ). The cartridge-based assay accurately detected all

54 allele patterns directly from 25 ul of whole blood. 
medRxiv preprint doi: https://doi.org/10.1101/2021.01.17.21249995; this version posted March 4, 2021. The copyright holder for this preprint

(which was not certified by peer review) is the author/funder, who has granted medRxiv a license to display the preprint in perpetuity.

All rights reserved. No reuse allowed without permission.

55 Conclusions: An automated pharmacogenomic assay on a platform widely used globally for

56 tuberculosis diagnosis could enable personalized dosing of isoniazid.

57 Keywords: tuberculosis; isoniazid; pharmacogenomic; molecular diagnostic; NAT2

58

59 
medRxiv preprint doi: https://doi.org/10.1101/2021.01.17.21249995; this version posted March 4, 2021. The copyright holder for this preprint (which was not certified by peer review) is the author/funder, who has granted medRxiv a license to display the preprint in perpetuity.

All rights reserved. No reuse allowed without permission.

\section{INTRODUCTION}

61 Despite the availability of effective chemotherapeutic regimens for treatment and prevention of

62 tuberculosis, a substantial proportion of patients experience toxicities, fail treatment or develop

63 recurrent disease (1-3). Standardized, weight-based dosing of anti-tuberculosis treatment has

64 been the conventional approach to therapy, despite mounting evidence that inter-individual

65 variability in metabolism leads to highly variable drug levels $(4,5)$. High drug levels are strongly

66 associated with risk of toxicity, while low drug levels are a determinant of treatment failure, slow

67 response, and emergence of drug resistance. Hepatotoxicity is the most common adverse effect,

68 affecting up to $33 \%$ of patients receiving standard four-drug therapy (6) and leading to regimen

69 changes in up to $10 \%$ of patients (7). This toxicity is associated with increased costs, morbidity,

70 and occasional mortality, particularly among HIV co-infected individuals (8). Additionally, as

71 many as $3 \%$ of new tuberculosis cases experience treatment failure, and between 6-10\% relapse

72 within 2 years $(9,10)$. Pharmacokinetic variability to a single drug is associated with treatment

73 failure and acquired drug resistance $(11,12)$. One study found that individuals with at least one

74 drug below the recommended AUC threshold had a 14-fold increased risk of poor outcomes (13)

75 More than 50 years after its introduction, isoniazid (INH) remains one of the major first line

76 drugs used to treat active and latent tuberculosis infections $(14,15)$. There has been an increasing

77 number of genetic markers identified that predict metabolism and toxicities from various

78 antimicrobials. INH is among the most well characterized of these, with more than $80 \%$ of its

79 pharmacokinetic variability explained by mutations in the gene encoding arylamine $\mathrm{N}$ -

80 acetyltransferase 2 (NAT2), responsible for its metabolism in the liver (16-18). The primary step

81 in the metabolism of INH is acetylation, catalyzed by the NAT2 enzyme, resulting in the 
medRxiv preprint doi: https://doi.org/10.1101/2021.01.17.21249995; this version posted March 4, 2021. The copyright holder for this preprint (which was not certified by peer review) is the author/funder, who has granted medRxiv a license to display the preprint in perpetuity.

All rights reserved. No reuse allowed without permission.

82 formation of acetyl-INH. The NAT2 enzyme displays genetic polymorphism, and its activity is

83 expressed at highly variable levels. A high correlation between INH acetylator phenotype and

84 seven most frequent SNPs in NAT2 gene has been demonstrated by several studies (19-22).

85 Individuals can be classified into three phenotypes-rapid, intermediate, and slow acetylators-

86 according to whether they carry polymorphisms on neither, one, or both copies of this gene,

87 respectively. Rapid acetylators typically have the lowest plasma INH concentrations, while slow

88 acetylators have high concentrations (23). A worldwide population survey on NAT2 acetylation

89 phenotype reported that more than half of the global population are slow or rapid acetylators

90 (18). A meta-analysis of 14 studies, comprising 474 cases and 1446 controls based on NAT2

91 polymorphisms found that rapid acetylators are twice as likely to have microbiological failure

92 and acquired drug resistance. Additionally, a significant association has been consistently

93 observed between NAT2 slow acetylators and the risk of anti-tuberculosis drug-induced liver

94 injury (17). Additional meta-analyses have identified a three- to four-fold increased risk of

95 hepatotoxicity among slow acetylators (24). A randomized trial of pharmacogenomic guided

96 dosing for tuberculosis treatment found that, compared with standard dosing, it reduced

97 hepatotoxicity among slow acetylators and increased treatment response at 8 weeks among rapid

98 acetylators (25)

99

100 Despite this evidence, pharmacogenomic testing and guided treatment has not entered the

101 mainstream of clinical practice for tuberculosis. Few clinical laboratories perform NAT2

102 genotyping, which requires detection of multiple polymorphisms and testing for heterozygous

103 allele patterns. Such testing is not widely available in resource-constrained environments where

104 the majority of tuberculosis burden falls. To address this gap, we developed an algorithm from 
105 unphased SNP patterns, derived from globally representative genomic data, to predict INH

106 metabolism phenotype using fewer SNPs while retaining high accuracy. Based on the SNP

107 combination derived from this model, we further developed a prototype NAT2 pharmacogenomic

108 (NAT2-PGx) assay on a commercial, automated PCR platform (GeneXpert) to detect NAT2

109 polymorphisms. We demonstrate that this tool can accurately predict INH clearance rates

110 directly from clinical samples and can be easily performed with minimal training and hands-on

111 time.

112

113 
medRxiv preprint doi: https://doi.org/10.1101/2021.01.17.21249995; this version posted March 4, 2021. The copyright holder for this preprint (which was not certified by peer review) is the author/funder, who has granted medRxiv a license to display the preprint in perpetuity.

\section{METHODS}

\section{Datasets}

116 The datasets used to develop the NAT2 classifier was obtained from the IGSR (International

117 Genome Sample Resource, 1000 genomes project) and a meta-analysis by Sabbagh et. al (18, 118 26). Population information on the combined dataset is provided in Supplementary Table 1.

120 NAT2 acetylator phenotype prediction classifier

121 Phased genomes from 8,561 individuals were used and haplotypes were labeled based on seven

122 most frequent SNPs (both synonymous and non-synonymous) which are reported to affect the 123 acetylation on INH - rs1801279 (191G>A), rs1041983 (282C>T), rs1801280 (341T>C), $124 \mathrm{rs} 1799929(481 \mathrm{C}>\mathrm{T}), \mathrm{rs} 1799930(590 \mathrm{G}>\mathrm{A}), \mathrm{rs} 1208(803 \mathrm{~A}>\mathrm{G})$ and $\mathrm{rs} 1799931(857 \mathrm{G}>\mathrm{A})(19)$ in 125 the NAT2 gene, following an international consensus nomenclature (27). We then constructed an 126 unphased dataset containing only information on whether each sample was wild type for both 127 alleles, homozygous variant for both alleles, or heterozygous. We stratified the dataset by 128 geographic region and then drew a random sample from two-thirds of each stratum for a training

129 set and one third for an out-of-sample test set, to ensure geographic representativeness in the 130 training and test sets. We trained random forest models on the training set using the caret 131 package in $\mathrm{R}$ and assessed classification performance on the held-out test set. We began with a 7 132 SNP model and eliminated SNPs in sequential models according to the lowest variable 133 importance factor. 
medRxiv preprint doi: https://doi.org/10.1101/2021.01.17.21249995; this version posted March 4, 2021. The copyright holder for this preprint (which was not certified by peer review) is the author/funder, who has granted medRxiv a license to display the preprint in perpetuity.

All rights reserved. No reuse allowed without permission.

136 The clinical study was approved by the institutional review boards of the Stanford University

137 School of Medicine and Federal University of Grande Dourados. All participants were over the

138 age of 18 and provided written informed consent. For assay optimization and validation on

139 GeneXpert cartridge, anonymized blood samples from healthy individuals were obtained from

140 Stanford blood center.

\section{Sample collection}

143 Sputum and plasma samples from 48 newly diagnosed patients with active pulmonary

144 tuberculosis were collected at the Federal University of Grande Dourados, Brazil. All

145 participants were treated with standardized, weight-based doses of isoniazid, rifampicin,

146 pyrazinamide and ethambutol. Plasma samples were collected at 1 hour and 8 hours after the first

147 dose and after 1 hour on day 14. Plasma drug concentrations for isoniazid and acetyl-isoniazid

148 were quantified by high-performance liquid chromatography coupled to tandem mass

149 spectrometry (HPLC-MS) as previously described (28).

\section{Pharmacokinetic analysis of INH clearance in tuberculosis patients}

152 The population PK analysis was performed using the non-linear mixed effects modeling 153 approach using NONMEM (version 7.4.3; ICON plc, Gaithersburg, MD, USA), PsN and R-

154 based Xpose (version 4.7 and higher) (29,30). One-compartment model with a first-order 155 absorption with a lognormal distribution for inter-individual variability (IIV) on different PK 156 parameter(s) as well as an additive and/or proportional model for the residual error were tested

157 for the base model selection. Mixture models with two or three subpopulations representing 158 different clearance rate were then evaluated. The first-order conditional estimation with 
medRxiv preprint doi: https://doi.org/10.1101/2021.01.17.21249995; this version posted March 4, 2021. The copyright holder for this preprint (which was not certified by peer review) is the author/funder, who has granted medRxiv a license to display the preprint in perpetuity.

All rights reserved. No reuse allowed without permission.

159 interaction method (FOCEI) was applied and the model-building procedure and model selection

160 was based on the log-likelihood criterion (the difference in the minimum OFV between

161 hierarchical models was assumed to be Chi-square distributed with degrees of freedom equal to

162 the difference in the number of parameters between models), goodness-of-fit plots (e.g. relevant

163 residuals against time randomly distributed around zero), and scientific plausibility of the model.

164 Visual predictive check was conducted to evaluate whether the final model with estimated fixed-

165 effect parameters and covariates adequately describe data.

\section{Sputum processing and host DNA extraction}

168 Spontaneously expectorated sputum samples from confirmed pulmonary tuberculosis patients

169 were collected in $10 \mathrm{~mL}$ of guanidine thiocyanate (GTC) solution. The samples were needle

170 sheared and centrifuged at $3000 \mathrm{rpm}$ for $30 \mathrm{~min}$. The supernatant was collected in Trizol LS and

171 host DNA was extracted from the supernatant using a manual extraction method described

172 previously (31).

\section{Primers and probes for melt curve analysis}

175 We first developed single-plex melt curve assays based on molecular beacon probe chemistry for

176 five NAT2 polymorphisms. Using same primer and probe sequences, we further developed

177 multiplex NAT2-PGx assay compatible on GeneXpert platform. Three sets of primers and five

178 molecular beacon probes spanning the NAT2 gene were used. Primers and probes were designed

179 using Beacon Designer (Premier Biosoft International, Palo, CA; version 8). A list of primers

180 and probes sequences with their corresponding fluorophores and quenchers is provided in

\section{Supplementary Table 2.}


medRxiv preprint doi: https://doi.org/10.1101/2021.01.17.21249995; this version posted March 4, 2021. The copyright holder for this preprint (which was not certified by peer review) is the author/funder, who has granted medRxiv a license to display the preprint in perpetuity.

\section{NAT2-genotyping on pulmonary TB samples}

183 Host genomic DNA extracted from 48 sputum samples from TB positive patients was used to

184 perform single-plex qPCR assays developed in-house. The assays were validated using TaqMan

185 commercial genotyping assays (NAT2 TaqMan® SNP Genotyping Assays, Applied

186 Biosystems). The genotyping was performed on StepOne Plus Real Time PCR (Applied

187 Biosystems). The NAT2-genotypes derived from the assays were used to predict INH acetylator 188 phenotype by our 5-SNP model.

\section{Automated NAT2-PGx Multiplex PCR and melt curve analysis}

191 We combined the five single-plex NAT2 melt curve assays validated on TB samples into one

192 and developed a multiplex assay (NAT2-PGx) on the FleXible Cartridge (Flex cart-01, Cepheid)

193 platform. Flex cart allows automated DNA extraction from whole blood followed by PCR

194 amplification and melt curve analysis to detect SNPs in NAT2 gene in a single run. NAT2-PGx

195 assay was performed on a GeneXpert IV instrument using GeneXpert Dx 4.8 software (Cepheid,

196 Sunnyvale). Briefly, 100ul of whole blood was mixed with 900ul of GeneXpert lysis buffer for

197 whole blood (Cepheid), incubated for $2 \mathrm{~min}$ at room temperature and loaded into sample

198 preparation chamber of the flex cart for automated DNA extraction. A 70ul of PCR mastermix

199 was simultaneously loaded in the PCR reaction chamber of the flex cart-01. PCR and melt

200 conditions were optimized using mastermix prepared in house.

201 We validated the multiplex assay on blood samples from 20 healthy individuals. The accuracy of

202 multiplex NAT2-PGx assay in SNP calling was subsequently validated by Sanger sequencing

203 (see methods). We assessed analytical sensitivity of the assay and robustness to input blood

204 volume by performing it on varying volumes of whole blood (200 ul, $100 \mathrm{ul}, 50 \mathrm{ul}, 25 \mathrm{ul})$ and 
medRxiv preprint doi: https://doi.org/10.1101/2021.01.17.21249995; this version posted March 4, 2021. The copyright holder for this preprint (which was not certified by peer review) is the author/funder, who has granted medRxiv a license to display the preprint in perpetuity.

All rights reserved. No reuse allowed without permission.

comparing the Tm results and standard deviation for each position across blood volumes. Additional details on the qPCR run method and melt curve analysis is provided in an online data

207 supplement.

\section{RESULTS}

210 SNP selection and development of acetylation prediction model

211 Complete phased data for the seven polymorphisms that define acetylation haplotypes were

212 available for 8,561 individuals from 59 populations. The dataset contains 3,573 (41.7\%)

213 individuals with a slow genotype, 3,428 (40.0\%) individuals with an intermediate genotype, and

214 1,560 (18.2\%) individuals with a rapid genotype (See Table 1). The highest proportion of rapid

215 acetylators were in East Asia (40\%), and three regions had prevalence of slow acetylator

216 phenotypes over 50\% (Central and South Asia, Europe and North Africa). We used these phased

217 allele data to select SNPs for inclusion in an assay measuring unphased SNPs. Using a random

218 forest model trained on two thirds of the data $(n=5,738)$, out-of-sample phenotype prediction

219 accuracy from unphased data on the remaining one third $(n=2,823)$ was $100 \%$ for models using

2207,6 or 5 SNPs. With 4 SNPs, prediction accuracy was 98.0\% (95\% CI: 97.4-98.5\%), and a 3

221 SNP model had similar performance (98.0\%; 95\% CI: 97.4-98.4\%) (Table 2). However, both of

222 these models performed poorly on data from Sub-Saharan Africa (4 SNP model accuracy:

223 82.5\%, 95\% CI: 78.1-86.4\%); 3 SNP model accuracy: 81.3\%, 95\% CI: 76.8-85.3\%). Based on

224 these results, we selected the 5 SNP model $(191 \mathrm{G}>\mathrm{A}, 282 \mathrm{C}>\mathrm{T}, 341 \mathrm{~T}>\mathrm{C}, 590 \mathrm{G}>\mathrm{A}$ and $857 \mathrm{G}>\mathrm{A})$

225 to take forward for clinical validation and diagnostic development.

227 Genotype correlation with isoniazid clearance in patients with tuberculosis 
medRxiv preprint doi: https://doi.org/10.1101/2021.01.17.21249995; this version posted March 4, 2021. The copyright holder for this preprint (which was not certified by peer review) is the author/funder, who has granted medRxiv a license to display the preprint in perpetuity.

All rights reserved. No reuse allowed without permission.

228 We enrolled a cohort of 48 patients with newly diagnosed pulmonary tuberculosis and collected 229 plasma at 1 hour and 8 hours after dose on day 1 and at 1 hour after dose on day 14. To detect

230 five NAT2 polymorphisms identified by our classifier, we performed single-plex melt curve 231 qPCR assays developed in-house using host DNA extracted from sputum samples. Additionally,

232 we used commercial 7-SNP single-plex genotyping assays and compared the results with 5-SNP 233 single-plex PCR to validate the melt curve accuracy in SNP detection. There was 100\% 234 concordance in terms of SNP detection between single-plex melt curve and commercial 7-SNP 235 assays. Of the 48 individuals for whom NAT2 genotypes were profiled, DNA-probe hybrid 236 melting temperature difference $(\Delta \mathrm{Tm})\left({ }^{\circ} \mathrm{C}\right)$ between wild-type and mutant alleles for positions $237191,282,341,590$ and 857 were found to be 4.38, 4.04, 2.40, 3.63 and 3.68 respectively. Both 238 mutant and wild type probes had a minimum $2.40^{\circ} \mathrm{C}$ Tm difference which allowed SNP calling 239 with high accuracy (Table 3).

241 We further predicted phenotypes from 5-SNP using the algorithm described above as well as a 242 publicly available tool (NAT2Pred) (32), which uses a 6 SNP model that excludes rs1801279 243 (191G>A) and includes other two sites from 7-SNP model- rs1799929 (481C>T) and rs1208

$244(803 \mathrm{~A}>\mathrm{G})$ when compared with our 5-SNP model. Among the 48 participants, predicted 245 acetylator types from the 5 SNP assay were: $27(56.2 \%)$ slow, $16(33.3 \%)$ intermediate and 5 $246(10.4 \%)$ rapid. NAT2Pred classified 4 samples as intermediate that were classified as rapid $(\mathrm{n}=1)$ 247 or slow $(\mathrm{n}=3)$ by the 5 SNP classifier. Among those classified as slow by the 5 SNP classifier 248 and intermediate by NAT2Pred, acetyl-INH to INH ratios at 8 hours were $0.61,0.38,0.41$, 249 consistent with slow acetylation (median: 0.76, range 0.36-1.55) rather than intermediate 250 acetylation (median 6.67, range 3.32-22.21) and suggesting misclassification by NAT2Pred. The 
medRxiv preprint doi: https://doi.org/10.1101/2021.01.17.21249995; this version posted March 4, 2021. The copyright holder for this preprint (which was not certified by peer review) is the author/funder, who has granted medRxiv a license to display the preprint in perpetuity.

All rights reserved. No reuse allowed without permission.

251 sample classified as intermediate by NAT2PRed and rapid by the 5 SNP classifier had an acetyl-

252 INH to INH ratio of 9.8, which fell between the median values, and within both ranges, for

253 intermediate and rapid acetylators (range $8.09-\infty$ ) (Supplementary Table-3). Phenotypes

254 predicted by the 5 SNP classifier were strongly predictive of INH acetylation and clearance

255 (Figure 1a and 1b). INH clearance rates were lowest in slow acetylators (median 19.3 L/hr),

256 moderate in intermediate acetylators (median $41.0 \mathrm{~L} / \mathrm{hr}$ ) and highest in fast acetylators (median

$257 \quad 46.7 \mathrm{~L} / \mathrm{hr})$.

258

259 Development of an automated pharmacogenomic assay

260 We validated the NAT2-PGx assay on 20 whole blood samples from healthy individuals. The

261 hands-on time for the cartridge preparation per sample was 5 minutes followed by 140 minutes

262 for overall run that included automated DNA extraction (Figure 2). Mutant, wild-type and

263 heterozygous alleles were manually called based on peak patterns and Tm values detected in

264 melt curves. Negative derivative transformed melt curves from five NAT2 gene polymorphisms

265 are shown in Figure 3. The assay detected all polymorphisms with $100 \%$ accuracy (average SD

266 in Tm across all probes $=0.34^{\circ} \mathrm{C}$ ) compared with Sanger sequencing. The NAT2 genotypes

267 corresponding to 20 blood samples covered all three categories - mutant, wild-type and

268 heterozygous for five NAT2 positions except for NAT2-191 for which all samples were all wild-

269 type. The $191 \mathrm{G}>\mathrm{A}$ mutation is highly prevalent in African and African-American populations

270 and is less common in other populations (33). Among the 20 samples, predicted acetylator types

271 using the 5-SNP classifier were: $8(40 \%)$ slow, $10(50 \%)$ intermediate and $2(10 \%)$ rapid

272 (Supplementary Table 4a).

273 
274 We further assessed the analytic performance of the NAT2-PGx assay at lower sample volumes.

275 Our assay could accurately detect all melt peaks with as low as $25 \mathrm{ul}$ of sample volume. The

276 variability in Tm from five NAT2 probes for sample volumes 200ul-25ul is shown in Figure 4.

277 NAT2 polymorphisms were accurately detected at all volumes (Supplementary Table 4b) and

278 demonstrated robustness to variation in input volume. 
medRxiv preprint doi: https://doi.org/10.1101/2021.01.17.21249995; this version posted March 4, 2021. The copyright holder for this preprint (which was not certified by peer review) is the author/funder, who has granted medRxiv a license to display the preprint in perpetuity.

All rights reserved. No reuse allowed without permission.

\section{DISCUSSION}

281 Despite availability of effective treatment for drug-sensitive tuberculosis, a substantial

282 proportion of population encounters drug associated toxicity or treatment failure, much of which

283 could be averted through dosing guided by genetic markers of drug metabolism (34). We

284 previously found that pharmacogenomic guided dosing of isoniazid could be highly cost-

285 effective in low- and middle-income countries (35). A major barrier to its implementation has

286 been the lack of a simple, scalable assay that could be used at points of care where tuberculosis is

287 treated in resource-constrained settings. To address this gap, we used globally representative

288 genomic data to identify patterns of 5 SNPs that enable accurate prediction of isoniazid

289 acetylator phenotype, validating this with pharmacokinetic data of patients receiving tuberculosis

290 treatment. We then developed a prototype automated pharmacogenomic assay on the GeneXpert

291 platform, which is widely available globally but had never been applied to pharmacogenomics.

292 We found that this assay could robustly distinguish wild type, mutant and heterozygous alleles

293 from a range of blood volumes as low as 25 ul, making it suitable for use with venous blood

294 samples or finger-stick blood samples. The assay requires minimal hands-on time for sample

295 preparation, which would facilitate its use in resource-constrained settings.

297 An earlier model ("NAT2Pred") predicted NAT2 acetylation phenotype from unphased genomic

298 data; however, it had moderate error rates in distinguishing intermediate from rapid acetylators

299 (33). Moreover, error rates among individuals from Sub-Saharan Africa were 14\%, in part due to

300 the exclusion of the G191A (R64Q) SNP, common to the NAT2 *14 allele cluster, which is

301 frequent in Africans and African-Americans, but virtually absent in Caucasian, Indian, and

302 Korean populations (36). A recent study using the set of 6 NAT2 SNPs included in NAT2Pred, 
medRxiv preprint doi: https://doi.org/10.1101/2021.01.17.21249995; this version posted March 4, 2021. The copyright holder for this preprint (which was not certified by peer review) is the author/funder, who has granted medRxiv a license to display the preprint in perpetuity.

All rights reserved. No reuse allowed without permission.

303 but not including G191A, found no correlation between NAT2 genotype and INH acetylation

304 phenotype in HIV-infected, Zulu individuals with culture-confirmed tuberculosis in Durban,

305 South Africa (37), underscoring the importance of including this SNP in genotype predictions in

306 this region.

307

308 Indeed, ethnic differences in SNP frequencies are responsible for the differences in frequency of

309 rapid, intermediate and slow acetylator NAT2 haplotypes (18, 23). We trained our SNP classifier

310 with globally representative data, which resulted in the selection and inclusion of the G191A

311 SNP in our model and assay. This is particularly important as Sub-Saharan Africa bears a

312 substantial burden of tuberculosis disease and mortality as well as HIV co-infection, which is

313 independently associated with greater pharmacokinetic variability and tuberculosis treatment

314 toxicity $(38,39)$.

316 The association between acetylation polymorphisms and INH metabolism was first demonstrated

317 in 1959, and their importance was well characterized in subsequent decades through phenotypic

318 descriptions (40-42). Subsequent genotypic descriptions confirmed that NAT2 polymorphisms

319 predicted INH early bactericidal activity, and clinical outcomes including hepatotoxicity, relapse

320 and acquisition of drug resistance. Further dosing studies demonstrated that provision of lower

321 doses to slow acetylators and higher doses to rapid acetylators could achieve target

322 concentrations (43). One randomized trial of pharmacogenomic-guided dosing of INH during

323 active tuberculosis treatment found that it significantly reduced toxicities (among slow

324 acetylators) and treatment non-response (among rapid acetylators). Taken together, the evidence

325 for pharmacogenomic guided dosing to achieve consistent drug levels and improve clinical 
medRxiv preprint doi: https://doi.org/10.1101/2021.01.17.21249995; this version posted March 4, 2021. The copyright holder for this preprint (which was not certified by peer review) is the author/funder, who has granted medRxiv a license to display the preprint in perpetuity.

All rights reserved. No reuse allowed without permission.

326 outcomes is strong. Automated, easy-to-use assays could enable pharmacogenomic guided

327 isoniazid dosing in resource constrained settings, where a substantial burden of the world's

328 tuberculosis occurs.

329 The findings of this study are subject to several limitations. We tested the assays on 48

330 individuals with active tuberculosis and 20 healthy individuals with a diverse representation of

331 polymorphisms, but the number of participants with G191A mutations was limited $(n=5)$. A

332 larger validation study involving testing on whole blood, including from finger stick capillary

333 blood, is needed to assess real-world performance of this assay under field conditions. Due to

334 unavailability of whole blood samples from TB patients, we used sputum samples to extract host

335 DNA for genotyping. Further studies should also investigate testing on non-invasive samples

336 including sputum, saliva or oral swabs, from which DNA is abundant. Second, we focused on

337 NAT2 polymorphisms, as they explain majority of interindividual pharmacokinetic variability,

338 though polymorphisms in several other genes have been associated with hepatotoxicity.

339 However, these associations have been comparatively modest and somewhat inconsistent (44-

340 45). We focused on INH and did not include other important tuberculosis drugs, such as

341 rifampicin. The evidence base for pharmacogenomic markers predicting rifampin

342 pharmacokinetics is less robust, and findings concerning clinical outcomes such as toxicities or

343 treatment response are limited (46-49). However, given the importance of this drug class in

344 treatment of active and latent tuberculosis, and emerging evidence supporting greater efficacy of

345 higher doses of rifampin, further investigation of pharmacogenomic markers in rifampicin is

346 needed. Future assays may include polymorphisms influencing rifampicin metabolism to further

347 optimize treatment of tuberculosis. 
medRxiv preprint doi: https://doi.org/10.1101/2021.01.17.21249995; this version posted March 4, 2021. The copyright holder for this preprint (which was not certified by peer review) is the author/funder, who has granted medRxiv a license to display the preprint in perpetuity.

All rights reserved. No reuse allowed without permission.

349 Since the demonstration of the efficacy of six month, short-course chemotherapy in 1979,

350 standardized treatment for drug susceptible tuberculosis using weight-based doses has remained

351 essentially unchanged. Additionally, INH remains a major component of regimens for treatment

352 of latent tuberculosis, which is recommended by the WHO for young children, HIV-infected

353 individuals and household contacts of tuberculosis cases (50). More than half the world's

354 population have slow or rapid acetylation phenotypes, which put them at risk for excessive drug

355 levels resulting in drug toxicities or insufficient drug levels putting them at risk of acquired drug

356 resistance or disease relapse. Dose adjustment based on NAT2 acetylation genotyping can

357 achieve consistent, target drug levels and reduce the incidence of poor clinical outcomes. We

358 developed a prototype automated, cartridge-based assay that can reliably predict acetylation

359 phenotype directly from as low as 25 ul of whole blood. By developing this for the GeneXpert

360 platform, which is widely used in low- and middle-income countries for tuberculosis diagnosis,

361 this assay could make personalized tuberculosis treatment dosing available in resource-

362 constrained settings. Further studies are needed to evaluate its accuracy and clinical impact in

363 real-world clinical settings.

366 Funding

367 FleXcartridges and technical support for their use were provided by Cepheid. This study was

368 supported by the Institute for Immunity, Transplantation, and Infection and the Department of

369 Medicine at Stanford University.

370

371 Data availability 
medRxiv preprint doi: https://doi.org/10.1101/2021.01.17.21249995; this version posted March 4, 2021. The copyright holder for this preprint

(which was not certified by peer review) is the author/funder, who has granted medRxiv a license to display the preprint in perpetuity.

All rights reserved. No reuse allowed without permission.

372 Data supporting the findings of this manuscript are available in the Supplementary Information

373 files or from the corresponding author upon request.

374 


\section{Acknowledgements}

376 We thank Veronique Dartois for performing the plasma drug level assays.

\section{Author contributions}

379 JRA and RV conceived of the study. RV, JC, and JRA designed the experiments. RV, SP,

380 FMM, MTV, ASS and JC collected data. RV, NZ, RS and JRA analyzed data. EW, DG and DP

381 provided technical guidance on the assay development. RV and JRA wrote the first draft of the

382 manuscript, and all authors contributed to the final version.

\section{Conflicts of Interest}

384 JRA and RV are named co-inventors on a provisional patent (Application number 62/991,477) for

385 a NAT2 pharmacogenomic assay. 
medRxiv preprint doi: https://doi.org/10.1101/2021.01.17.21249995; this version posted March 4, 2021. The copyright holder for this preprint (which was not certified by peer review) is the author/funder, who has granted medRxiv a license to display the preprint in perpetuity.

\section{References}

1. Gillespie SH, Crook AM, McHugh TD, Mendel CM, Meredith SK, Murray SR, Pappas F, Phillips PP, Nunn AJ; REMoxTB Consortium. Four-month moxifloxacin-based regimens for drug-sensitive tuberculosis. N Engl J Med. 2014 Oct 23;371(17):1577-87. doi: 10.1056/NEJMoa1407426. Epub 2014 Sep 7.

2. Merle CS, Fielding K, Sow OB, Gninafon M, Lo MB, Mthiyane T, Odhiambo J, Amukoye E, Bah B, Kassa F, N'Diaye A, Rustomjee R, de Jong BC, Horton J, Perronne C, Sismanidis C, Lapujade O, Olliaro PL, Lienhardt C; OFLOTUB/Gatifloxacin for Tuberculosis Project. A four-month gatifloxacin-containing regimen for treating tuberculosis. N Engl J Med. 2014

3. Jindani A, Harrison TS, Nunn AJ, Phillips PP, Churchyard GJ, Charalambous S, Hatherill M, Geldenhuys H, McIlleron HM, Zvada SP, Mungofa S, Shah NA, Zizhou S, Magweta L, Shepherd J, Nyirenda S, van Dijk JH, Clouting HE, Coleman D, Bateson AL, McHugh TD, Butcher PD, Mitchison DA; RIFAQUIN Trial Team. High-dose rifapentine with moxifloxacin for pulmonary tuberculosis. N Engl J Med. 2014 Oct 23;371(17):1599-608. A GeT-RM Collaborative Project. J Mol Diagn. 2016 Jan;18(1):109-23.

406 5. García-Martín E. Interethnic and intraethnic variability of NAT2 single nucleotide polymorphisms. Curr Drug Metab. 2008 Jul;9(6):487-97. 
medRxiv preprint doi: https://doi.org/10.1101/2021.01.17.21249995; this version posted March 4, 2021. The copyright holder for this preprint (which was not certified by peer review) is the author/funder, who has granted medRxiv a license to display the preprint in perpetuity.

All rights reserved. No reuse allowed without permission.

6. Schaberg T, Rebhan K, Lode H. Risk factors for side-effects of isoniazid, rifampin and pyrazinamide in patients hospitalized for pulmonary tuberculosis. Eur Respir J. 1996 Oct;9(10):2026-30.

7. Saukkonen JJ, Cohn DL, Jasmer RM, Schenker S, Jereb JA, Nolan CM, Peloquin CA, Gordin FM, Nunes D, Strader DB, Bernardo J, Venkataramanan R, Sterling TR; ATS (American Thoracic Society) Hepatotoxicity of Antituberculosis Therapy Subcommittee. An official ATS statement: hepatotoxicity of antituberculosis therapy. Am J Respir Crit Care Med. 2006 Oct 15;174(8):935-52.

8. Schutz C, Ismail Z, Proxenos CJ, Marais S, Burton R, Kenyon C, Maartens G, Wilkinson RJ, Meintjes G. Burden of antituberculosis and antiretroviral drug-induced liver injury at a secondary hospital in South Africa. S Afr Med J. 2012 Mar 2;102(6):506-11.

9. Luzze H, Johnson DF, Dickman K, Mayanja-Kizza H, Okwera A, Eisenach K, Cave MD, Whalen CC, Johnson JL, Boom WH, Joloba M; Tuberculosis Research Unit. Relapse more common than reinfection in recurrent tuberculosis 1-2 years post treatment in urban Uganda. Int J Tuberc Lung Dis. 2013 Mar;17(3):361-7.

10. Romanowski K, Balshaw RF, Benedetti A, Campbell JR, Menzies D, Ahmad Khan F, Johnston JC. Predicting tuberculosis relapse in patients treated with the standard 6-month regimen: an individual patient data meta-analysis. Thorax. 2019 Mar;74(3):291-297.

11. Pasipanodya JG, Srivastava S, Gumbo T. Meta-analysis of clinical studies supports the pharmacokinetic variability hypothesis for acquired drug resistance and failure of antituberculosis therapy. Clin Infect Dis. 2012 Jul;55(2):169-77.

12. Gumbo T, Louie A, Liu W, Brown D, Ambrose PG, Bhavnani SM, Drusano GL. Isoniazid bactericidal activity and resistance emergence: integrating pharmacodynamics and 
pharmacogenomics to predict efficacy in different ethnic populations. Antimicrob Agents Chemother. 2007 Jul;51(7):2329-36.

433 13. Pasipanodya JG, McIlleron H, Burger A, Wash PA, Smith P, Gumbo T. Serum drug 434 concentrations predictive of pulmonary tuberculosis outcomes. J Infect Dis. 2013 Nov 1;208(9):1464-73.

436 14. Hall RG, Leff RD, Gumbo T. Treatment of active pulmonary tuberculosis in adults: current standards and recent advances. Insights from the Society of Infectious Diseases Pharmacists. Pharmacotherapy. 2009 Dec;29(12):1468-81

439 15. Sterling TR, Njie G, Zenner D, et al. Guidelines for the Treatment of Latent Tuberculosis Infection: Recommendations from the National Tuberculosis Controllers Association and

16. Kinzig-Schippers M, Tomalik-Scharte D, Jetter A, Scheidel B, Jakob V, Rodamer M, Cascorbi I, Doroshyenko O, Sörgel F, Fuhr U. Should we use N-acetyltransferase type 2

446 17. Du H, Chen X, Fang Y, Yan O, Xu H, Li L, Li W, Huang W. Slow N-acetyltransferase 2 447 genotype contributes to anti-tuberculosis drug-induced hepatotoxicity: a meta-analysis. Mol 448 Biol Rep. 2013 May;40

449 18. Sabbagh A, Langaney A, Darlu P, Gérard N, Krishnamoorthy R, Poloni ES. Worldwide 450 distribution of NAT2 diversity: implications for NAT2 evolutionary history. BMC Genet. $451 \quad 2008$ Feb 27;9:21. 
medRxiv preprint doi: https://doi.org/10.1101/2021.01.17.21249995; this version posted March 4, 2021. The copyright holder for this preprint (which was not certified by peer review) is the author/funder, who has granted medRxiv a license to display the preprint in perpetuity.

All rights reserved. No reuse allowed without permission.

452 19. Wang PY, Xie SY, Hao Q, Zhang C, Jiang BF. NAT2 polymorphisms and susceptibility to 453 anti-tuberculosis drug-induced liver injury: a meta-analysis. Int J Tuberc Lung Dis. 2012 454 May;16(5):589-95.

455 20. Parkin DP, Vandenplas S, Botha FJ, Vandenplas ML, Seifart HI, van Helden PD, van der 456 Walt BJ, Donald PR, van Jaarsveld PP. Trimodality of isoniazid elimination: phenotype and 457 genotype in patients with tuberculosis. Am J Respir Crit Care Med. 1997 May;155(5):171722.

459 21. Gross M, Kruisselbrink T, Anderson K, Lang N, McGovern P, Delongchamp R, Kadlubar F. 460 Distribution and concordance of N-acetyltransferase genotype and phenotype in an 461 American population. Cancer Epidemiol Biomarkers Prev. 1999 Aug;8(8):683-92.

462 22. Mrozikiewicz PM, Cascorbi I, Brockmöller J, Roots I. Determination and allelic allocation 463 of seven nucleotide transitions within the arylamine $\mathrm{N}$-acetyltransferase gene in the Polish 464 population. Clin Pharmacol Ther. 1996 Apr;59(4):376-82.

465 23. Hein DW, Doll MA. Accuracy of various human NAT2 SNP genotyping panels to infer 466 rapid, intermediate and slow acetylator phenotypes. Pharmacogenomics. 2012 Jan;13(1):31$467 \quad 41$.

468 24. Snider DE Jr, Caras GJ. Isoniazid-associated hepatitis deaths: a review of available 469 information. Am Rev Respir Dis. 1992 Feb;145(2 Pt 1):494-7.

470 25. Azuma J, Ohno M, Kubota R, Yokota S, Nagai T, Tsuyuguchi K, Okuda Y, Takashima T, 471 Kamimura S, Fujio Y, Kawase I; Pharmacogenetics-based tuberculosis therapy research 472 group. NAT2 genotype guided regimen reduces isoniazid-induced liver injury and early 473 treatment failure in the 6-month four-drug standard treatment of tuberculosis: a randomized 
controlled trial for pharmacogenetics-based therapy. Eur J Clin Pharmacol. 2013 May;69(5):1091-101.

476 26. McInnes G and Russ A. Drug Response Pharmacogenetics for 200,000 UK Biobank 477 Participants.

478 27. Database of arylamine $N$-acetyltransferases (http://nat.mbg.duth.gr)

479 28. Prideaux B, Via LE, Zimmerman MD, Eum S, Sarathy J, O'Brien P, Chen C, Kaya F, 480 Weiner DM, Chen PY, Song T, Lee M, Shim TS, Cho JS, Kim W, Cho SN, Olivier KN, 481 Barry CE 3rd, Dartois V. The association between sterilizing activity and drug distribution 482 into tuberculosis lesions. Nat Med. 2015 Oct;21(10):1223-7.

483 29. Beal SL. Et al. NONMEM 7.4 Users Guides. (1989- 2019). ICON plc, Gaithersburg, MD. 484 https://nonmem.iconplc.com/nonmem744

485 30. Lindbom L, Ribbing J, Jonsson EN. Perl-speaks-NONMEM (PsN)--a Perl module for 486 NONMEM related programming. Comput Methods Programs Biomed. 2004 Aug;75(2):8594.

31. Chomczynski P. A reagent for the single-step simultaneous isolation of RNA, DNA and proteins from cell and tissue samples. Biotechniques. 1993 Sep;15(3):532-4, 536-7. PMID: 7692896.

32. Kuznetsov

IB, McDuffie M, Moslehi R. A web server for inferring the human Nacetyltransferase-2 (NAT2) enzymatic phenotype from NAT2 genotype. Bioinformatics. 2009 May 1;25(9):1185-6.

494 33. Sabbagh A, Darlu P, Vidaud M. Evaluating NAT2PRED for inferring the individual 495 acetylation status from unphased genotype data. BMC Med Genet. 2009 Dec 31;10:148. 
medRxiv preprint doi: https://doi.org/10.1101/2021.01.17.21249995; this version posted March 4, 2021. The copyright holder for this preprint (which was not certified by peer review) is the author/funder, who has granted medRxiv a license to display the preprint in perpetuity.

All rights reserved. No reuse allowed without permission.

34. Ramachandran G, Swaminathan S. Role of pharmacogenomics in the treatment of tuberculosis: a review. Pharmgenomics Pers Med. 2012;5:89-98

35. Rens NE, Uyl-de Groot CA, Goldhaber-Fiebert JD, Croda J, Andrews JR. Costeffectiveness of a Pharmacogenomic Test for Stratified Isoniazid Dosing in Treatment of Active Tuberculosis. Clin Infect Dis. 2020 Dec 15;71(12):3136-3143.

36. Sabbagh A, Darlu P, Crouau-Roy B, Poloni ES. Arylamine N-acetyltransferase 2 (NAT2) genetic diversity and traditional subsistence: a worldwide population survey. PLoS One. 2011 Apr 6;6(4):e18507.

37. Mthiyane T, Millard J, Adamson J, Balakrishna Y, Connolly C, Owen A, Rustomjee R, Dheda K, McIlleron H, Pym AS. N-Acetyltransferase 2 Genotypes among Zulu-Speaking South Africans and Isoniazid and $N$-Acetyl-Isoniazid Pharmacokinetics during Antituberculosis Treatment. Antimicrob Agents Chemother. 2020 Mar 24;64(4):e02376-19.

38. van Oosterhout JJ, Dzinjalamala FK, Dimba A, Waterhouse D, Davies G, Zijlstra EE, Molyneux ME, Molyneux EM, Ward S. Pharmacokinetics of Antituberculosis Drugs in HIV-Positive and HIV-Negative Adults in Malawi. Antimicrob Agents Chemother. 2015 Oct;59(10):6175-80.

39. Wilkins JJ, Langdon G, McIlleron H, Pillai G, Smith PJ, Simonsson US. Variability in the population pharmacokinetics of isoniazid in South African tuberculosis patients. Br J Clin Pharmacol. 2011 Jul;72(1):51-62.

40. Iselius L, Evans DA. Formal genetics of isoniazid metabolism in man. Clin Pharmacokinet. 1983 Nov-Dec;8(6):541-4.

41. Evans DA. Genetic variations in the acetylation of isoniazid and other drugs. Ann N Y Acad Sci. 1968 Jul 31;151(2):723-33. 
medRxiv preprint doi: https://doi.org/10.1101/2021.01.17.21249995; this version posted March 4, 2021. The copyright holder for this preprint (which was not certified by peer review) is the author/funder, who has granted medRxiv a license to display the preprint in perpetuity.

All rights reserved. No reuse allowed without permission.

42. Evans DA. An improved and simplified method of detecting the acetylator phenotype. J Med Genet. 1969 Dec;6(4):405-7.

521 43. Naidoo A, Chirehwa M, Ramsuran V, McIlleron H, Naidoo K, Yende-Zuma N, Singh R,

522 Ncgapu S, Adamson J, Govender K, Denti P, Padayatchi N. Effects of genetic variability on 523 rifampicin and isoniazid pharmacokinetics in South African patients with recurrent 524 tuberculosis. Pharmacogenomics. 2019 Mar;20(4):225-240.

525 44. Wilkins JJ, Langdon G, McIlleron H, Pillai GC, Smith PJ, Simonsson US. Variability in the 526 population pharmacokinetics of pyrazinamide in South African tuberculosis patients. Eur J 527 Clin Pharmacol. 2006 Sep;62(9):727-35.

528 45. Lee SW, Chung LS, Huang HH, Chuang TY, Liou YH, Wu LS. NAT2 and CYP2E1 529 polymorphisms and susceptibility to first-line anti-tuberculosis drug-induced hepatitis. Int J 530 Tuberc Lung Dis. 2010 May;14(5):622-6.

531 46. Roy B, Ghosh SK, Sutradhar D, Sikdar N, Mazumder S, Barman S. Predisposition of 532 antituberculosis drug induced hepatotoxicity by cytochrome P450 2E1 genotype and 533 haplotype in pediatric patients. J Gastroenterol Hepatol. 2006 Apr;21(4):784-6.

534 47. Simon T, Becquemont L, Mary-Krause M, de Waziers I, Beaune P, Funck-Brentano C, 535 Jaillon P. Combined glutathione-S-transferase M1 and T1 genetic polymorphism and tacrine 536 hepatotoxicity. Clin Pharmacol Ther. 2000 Apr;67(4):432-7.

537 48. Strange RC, Jones PW, Fryer AA. Glutathione S-transferase: genetics and role in 538 toxicology. Toxicol Lett. 2000 Mar 15;112-113:357-63.

539 49. Mukonzo JK, Kengo A, Kutesa B, Nanzigu S, Pohanka A, McHugh TD, Zumla A, Aklillu 540 E. Role of pharmacogenetics in rifampicin pharmacokinetics and the potential effect on TB- 
medRxiv preprint doi: https://doi.org/10.1101/2021.01.17.21249995; this version posted March 4, 2021. The copyright holder for this preprint (which was not certified by peer review) is the author/funder, who has granted medRxiv a license to display the preprint in perpetuity.

All rights reserved. No reuse allowed without permission. 7;114(2):107-114.

543 50. Haley CA. Treatment of Latent Tuberculosis Infection. Microbiol Spectr. 2017 Apr;5(2).

Figure 1. Predicted NAT2 phenotype from sputum samples and associated acetylation ratio

547 acetyl-INH to INH ratio and (b) isonazid clearance rates, according to acetylation phenotype

548 predicted from 5 SNPs, measured in sputum samples from 48 patients receiving treatment for 549 active tuberculosis.

551 Figure 2. Schemata for the automated NAT2 Pharmacogenomic assay. 1-2 drops of blood is

552 collected in an Eppendorf tube and mixed with lysis buffer to a total of $1 \mathrm{ml}$, which is then

553 loaded onto a GeneXpert Flex01 cartridge and placed into a GeneXpert instrument for automated

554 DNA extraction, qPCR and meltcurve analysis. Allele patterns for each of the 5 SNPs are 555 determined by Tm analysis, and the resulting data are used to predict acetylator phenotype.

557 Figure 3. Negative derivative transformed melt curves for the five NAT2 gene

558 polymorphisms. The shift in melt curve temperature is observed during a nucleotide exchange.

559 Molecular beacon probes are first hybridized and then melted off of their NAT2 target amplicon.

560 The melt curves indicate wild type alleles at positions 191(red), 341(green) and 857 (orange); 561 and mutant alleles at positions 282(Blue) and 590(Purple).

562

563 Figure 4. Effect of whole blood sample volume on melting temperature for wild type and

564 mutant alleles at 5 positions in NAT2: NAT2 polymorphisms were accurately detected at all 
medRxiv preprint doi: https://doi.org/10.1101/2021.01.17.21249995; this version posted March 4, 2021. The copyright holder for this preprint (which was not certified by peer review) is the author/funder, who has granted medRxiv a license to display the preprint in perpetuity. All rights reserved. No reuse allowed without permission.

565 volumes with sufficient different in melting temperature $(\mathrm{Tm})$ to distinguish wild type from

566 mutant alleles. None of the individuals in this dataset had mutations at position 191. 
568 Table 1. Summary of populations included in genomic analysis and their acetylation

569 genotypes.

570

\section{Acetylation Genotype, n (\%)}

\section{Number of}

\begin{tabular}{lcccc} 
Region & individuals & Slow & Intermediate & Rapid \\
\cline { 3 - 4 } Americas & 1,112 & $432(39 \%)$ & $463(42 \%)$ & $217(20 \%)$ \\
Central and South Asia & 588 & $355(60 \%)$ & $198(34 \%)$ & $35(6 \%)$ \\
East Asia & 2,308 & $340(15 \%)$ & $1049(45 \%)$ & $919(40 \%)$ \\
Europe & 3,458 & $1966(57 \%)$ & $1249(36 \%)$ & $243(7 \%)$ \\
North Africa & 44 & $30(68 \%)$ & $10(23 \%)$ & $4(9 \%)$ \\
sub-Saharan Africa & 1,051 & $450(43 \%)$ & $459(44 \%)$ & $142(14 \%)$ \\
\hline Total & 8,561 & $3573(42 \%)$ & $3428(40 \%)$ & $1560(18 \%)$
\end{tabular}


medRxiv preprint doi: https://doi.org/10.1101/2021.01.17.21249995; this version posted March 4, 2021. The copyright holder for this preprint (which was not certified by peer review) is the author/funder, who has granted medRxiv a license to display the preprint in perpetuity.

All rights reserved. No reuse allowed without permission.

573 Table 2. Out-of-sample prediction accuracy of unphased NAT2 SNP data for acetylation

574 phenotype in random forest models. Models were trained with 5,738 individuals and tested on

5752,823 individuals. Sens: sensitivity. Spec: specificity.

576

\begin{tabular}{|c|c|c|c|c|c|c|c|}
\hline $\begin{array}{l}\text { NAT2 SNP } \\
\text { Positions }\end{array}$ & $\begin{array}{c}\text { SNP } \\
\text { number }\end{array}$ & Accuracy & $95 \% \mathrm{CI}$ & $\begin{array}{l}\text { Sens. } \\
\text { Rapid }\end{array}$ & $\begin{array}{l}\text { Spec. } \\
\text { Rapid }\end{array}$ & $\begin{array}{l}\text { Sens. } \\
\text { Slow }\end{array}$ & $\begin{array}{l}\text { Spec } \\
\text { Slow }\end{array}$ \\
\hline $\begin{array}{c}191,282,341,481 \\
590,803,857\end{array}$ & 7 & 1.000 & $(0.999-1.000)$ & 1.000 & 1.000 & 1.000 & 1.000 \\
\hline $\begin{array}{l}191,282,341, \\
481,590,857\end{array}$ & 6 & 1.000 & $(0.999-1.000)$ & 1.000 & 1.000 & 1.000 & 1.000 \\
\hline $\begin{array}{c}191,282,341 \\
590,857\end{array}$ & 5 & 1.000 & $(0.999-1.000)$ & 1.000 & 1.000 & 1.000 & 1.000 \\
\hline $\begin{array}{l}282,341, \\
590,857\end{array}$ & 4 & 0.978 & $(0.972-0.983)$ & 0.996 & 0.988 & 0.969 & 0.999 \\
\hline $\begin{array}{c}341,590, \\
847\end{array}$ & 3 & 0.976 & $(0.970-0.982)$ & 1.000 & 0.986 & 0.967 & 1.000 \\
\hline $\begin{array}{l}341, \\
590\end{array}$ & 2 & 0.852 & $(0.838-0.865)$ & 1.000 & 0.889 & 0.832 & 1.000 \\
\hline
\end{tabular}


581 Table 3. Melting temperature (Tm) values for five NAT2 polymorphisms derived from

582 DNA-probe hybrid melts using single-plex assays validated on 48 pulmonary TB patients

583

Mutant Wild type Het Mutant Wild type

$\Delta \mathrm{Tm}$

NAT2 SNP Total samples Total samples Total samples

position analyzed analyzed analyed

$$
\mathrm{Tm} \pm \mathrm{SD} \quad \mathrm{Tm} \pm \mathrm{SD} \quad(\mathrm{WT}-
$$

MT)

\begin{tabular}{|c|c|c|c|c|c|c|}
\hline 191 & 0 & 44 & 5 & $66.3 \pm 0.28$ & $\begin{array}{c}61.92 \pm \\
0.68\end{array}$ & 4.38 \\
\hline 282 & 6 & 24 & 19 & $62.81 \pm 0.40$ & $\begin{array}{c}66.85 \pm \\
0.34\end{array}$ & 4.04 \\
\hline 341 & 12 & 23 & 14 & $66.30 \pm 0.48$ & $\begin{array}{c}68.70 \pm \\
0.38\end{array}$ & 2.40 \\
\hline 590 & 0 & 35 & 14 & $68.0 \pm 0.28$ & $\begin{array}{c}64.37 \pm \\
0.28\end{array}$ & 3.63 \\
\hline 857 & 1 & 41 & 7 & $66.4 \pm 0.11$ & $\begin{array}{c}62.72 \pm \\
0.29\end{array}$ & 3.68 \\
\hline
\end{tabular}

584 SD: Standard deviation, $\Delta$ Tm: DNA-probe hybrid melting temperature difference, WT: Wild 585 type, MT: mutant 
587 Supplementary Table 1. Population information on the dataset used to develop the 5-SNP 588 classifier.

590 Supplementary Table 2. List of primers and probes sequences for multiplex assay with their 591 corresponding fluorophores and quenchers

593 Supplementary Table 3. NAT2 polymorphism profiles of 48 pulmonary TB patients detected 594 from 5-SNP and 7-SNP genotyping assays. Acetylator phenotypes predicted from 5-SNP, 6-SNP 595 and 7-SNP classifiers and plasma INH and acetyl-INH levels recorded at various time-points.

597 Supplementary Table 4. (a) NAT2 genotype of whole blood samples $(\mathrm{n}=20)$ analyzed on 5598 plex NAT2-PGx assay and validated on Sanger sequencing. (b) NAT2 genotypes of ten whole 599 blood samples analyzed using 200ul, 100ul, 50ul and 25ul samples 


\section{At a Glance Commentary}

Scientific Knowledge on the Subject: Standardized weight-based dose of isoniazid (INH) may result in variable drug levels in individuals leading to drug-induced toxicities, treatment failure and relapse. Polymorphisms in the NAT2 gene explain the majority of interindividual pharmacokinetic variability of INH. Pharmacogenomic guided dosing may improve treatment outcomes, but scalable assays are not available.

What This Study Adds to the Field: Earlier NAT2 acetylation prediction algorithms had diminished accuracy in African populations by failing to include a common polymorphism. We developed an algorithm on globally representative data that predicted acetylation genotype with $100 \%$ accuracy using 5 unphased SNPs. We tested the accuracy of this acetylator prediction algorithm against INH clearance rates in 48 pulmonary TB patients and found very strong high correlation. We then developed a cartridge-based multiplex assay for these 5 SNPs on the GeneXpert platform that can accurately detect NAT2 genotype from $25 \mathrm{ul}$ whole blood. Because this platform is widely used in low- and middle-income countries for tuberculosis diagnosis, this assay could make personalized isoniazid dosing available in resource-constrained settings. 
1 Sample
collection

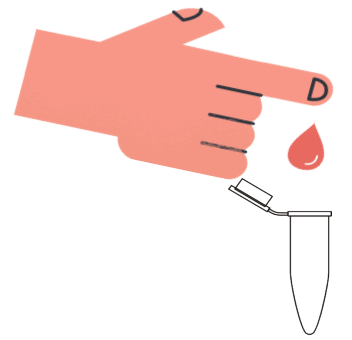

Collect 1-2 drops of whole blood (approx. 50ul)

(4) Automated DNA extraction \& qPCR

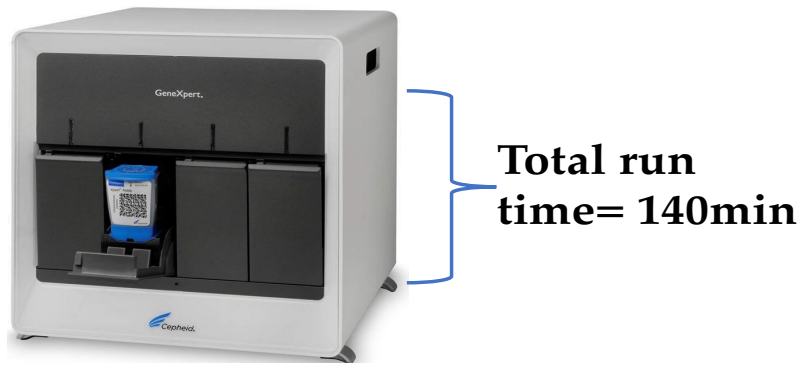

Load the cartridge in the GeneXpert machine and start the run

\section{(2) Whole blood pretreatment}

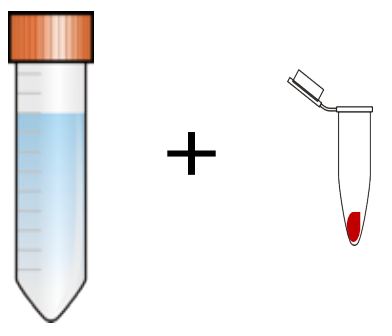

Mix 950ul lysis buffer, vortex for 2 sec and incubate at RT for $2 \mathrm{~min}$

\section{(5) Data aquisition}

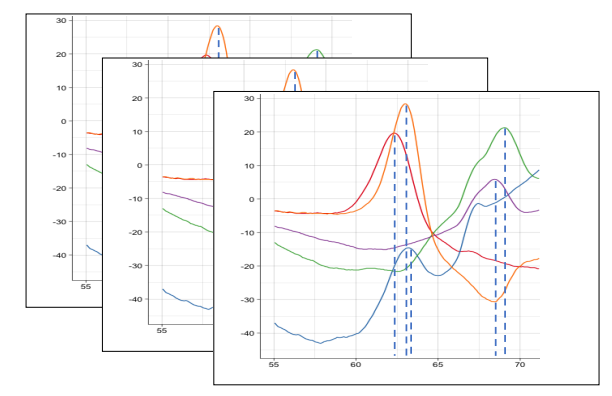

Acquire melt curve data for NAT2 gene polymorphism detection
(3) Flex cart01 preparation

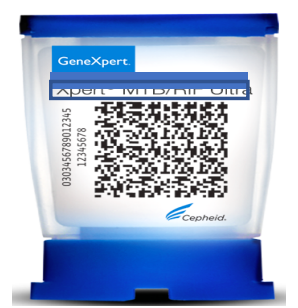

Pipette $1 \mathrm{ml}$ pretreated sample and 70ul PCR mastermix into the cartridge

\section{6) INH acetylator phenotype prediction}

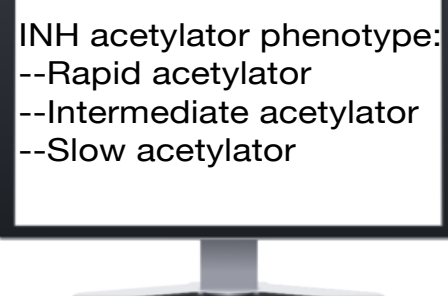

Upload NAT2 polymorphism data on phenotype prediction algorithm 
medRxiv preprint doi: https://doi.org/10.1101/2021.01.17.21249995; this version posted March 4, 2021. The copyright holder for this preprint (which was not certified by peer review) is the author/funder, who has granted medRxiv a license to display the preprint in perpetuity. All rights reserved. No reuse allowed without permission.

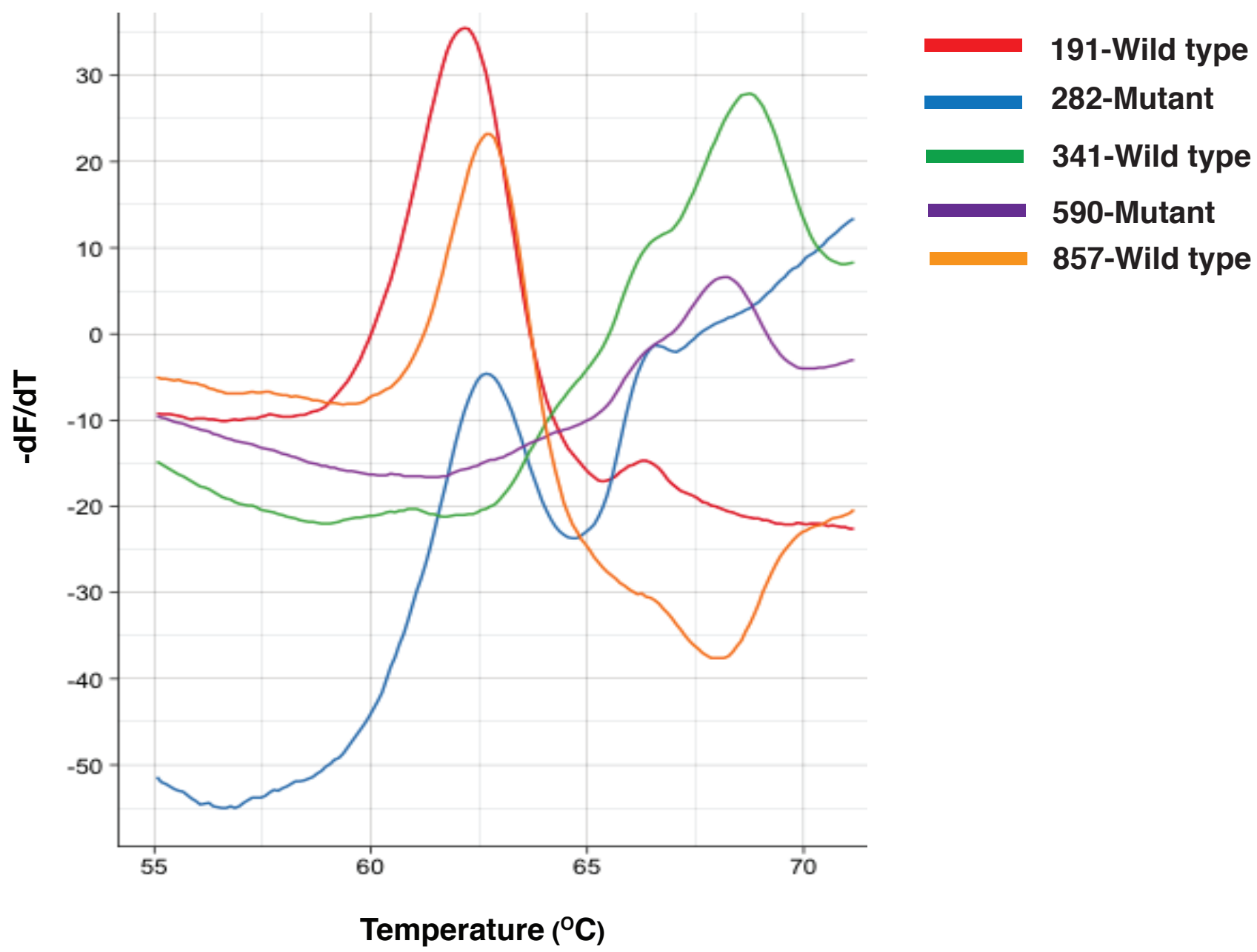


